\title{
A new age in AquaMedicine: unconventional approach in studying aquatic diseases
}

\author{
Michael Gotesman', Simon Menanteau-Ledouble ${ }^{2}$, Mona Saleh$^{2}$, Sven M. Bergmann ${ }^{3}$ and Mansour El-Matbouli ${ }^{2^{*}}$
}

\begin{abstract}
Background: Marine and aquaculture industries are important sectors of the food production and global trade. Unfortunately, the fish food industry is challenged with a plethora of infectious pathogens. The freshwater and marine fish communities are rapidly incorporating novel and most up to date techniques for detection, characterization and treatment strategies. Rapid detection of infectious diseases is important in preventing large disease outbreaks.
\end{abstract}

Main text: One hundred forty-six articles including reviews papers were analyzed and their conclusions evaluated in the present paper. This allowed us to describe the most recent development research regarding the control of diseases in the aquatic environment as well as promising avenues that may result in beneficial developments. For the characterization of diseases, traditional sequencing and histological based methods have been augmented with transcriptional and proteomic studies. Recent studies have demonstrated that transcriptional based approaches using qPCR are often synergistic to expression based studies that rely on proteomic-based techniques to better understand pathogen-host interactions. Preventative therapies that rely on prophylactics such as vaccination with protein antigens or attenuated viruses are not always feasible and therefore, the development of therapies based on small nucleotide based medicine is on the horizon. Of those, RNAi or CRISPR/Cas- based therapies show great promise in combating various types of diseases caused by viral and parasitic agents that effect aquatic and fish medicine.

Conclusions: In our modern times, when the marine industry has become so vital for feed and economic stability, even the most extreme alternative treatment strategies such as the use of small molecules or even the use of disease to control invasive species populations should be considered.

Keywords: Aquaculture, Virus, Bacteria, Nanotechnology, RNAi, CRISPR/Cas

\section{Background}

\section{Fish and aquatic industry}

The global annual per capita fish consumption of fish was $20.1 \mathrm{~kg}$ for the year 2013; with an average consumption of $26.8 \mathrm{~kg}$ in industrialized countries and $18.1 \mathrm{~kg}$ in developing countries, respectively [1]. Fish protein accounted for up to $20 \%$ or more of the total animal protein consumed in low-income food-deficient countries and around $17 \%$ globally in the year 2013 [1]. In addition to producing a critical part of nutrition, food

\footnotetext{
* Correspondence: Mansour.El-Matbouli@vetmeduni.ac.at

${ }^{2}$ Clinical Division of Fish Medicine, Department for Farm Animals and

Veterinary Public Health, University of Veterinary Medicine, Veterinärplatz 1 ,

1210 Vienna, Austria

Full list of author information is available at the end of the article
}

production through the marine industry also represents a major form of employment which harvested nearly 160 billion US dollars in 2014 and employed 56.6 million people [1]. Of the total 167.2 million tonnes of food products that the marine industry produced in 2014, the aquaculture accounted for $44.1 \%$ (73.8 million tonnes) production [1]. Carp (Cyprinidae) makes up a significant portion of the total freshwater cultured fish supply and is an especially important food in China and the remainder of East Asia, which produced 61.3 and $26.7 \%$ of cultured carp, respectively in 2010 [1,2]. Salmon and shrimp are considered high-value species that are heavily traded and are also significant members of the aquaculture industry [1]. 


\section{Viral diseases of fish and crustaceans in the aquatic industry}

Diseases of aquatic products, such as viral infection of aquatic animals, have become more problematic and are causing significant economical losses to the aquaculture industry [3-7]. The most serious viruses affecting cyprinid fish including koi and common carp (Cyprinus carpio L.) are: 1) Cyprinid herpesvirus 3 (CyHV-3), a member of the Alloherpesviridae family of viruses, which is the aetiological agent of a highly contagious disease termed Koi herpesvirus disease (KHVD) and 2) spring viraemia of carp virus (SVCV), which is a member of the Rhabdoviridae family of viruses. In addition, outbreaks of KHVD and SVC in cultured common carp caused significant economic losses in recent years. KHVD has been a major research topic in aquatic medicine and has been listed as a notifiable disease in Germany since 2005, in England and by the World Organization of Animal Health (OIE) since 2007 [8-13]. Similarly, the SVC is a major topic of aquatic research and is listed as a notifiable disease in the USA, and has been listed by the OIE since 1997 [14, 15]. Hemorrhagic septicemia virus (VHSV) is another pathogenic member of Rhabdoviridae known to infect northern pike, Esox lucius fry [16]. Members of the Rhabdoviridae family of viruses that code for the non-virion protein (NV) are subtyped into their own genus termed Novirhabdovirus; such as infectious hematopoietic necrosis virus (IHNV), which causes an OIE notifiable disease and is an economically important in a wide variety of salmonid species [17]. Infectious salmon anemia virus (ISAV) the causative agent of the ISA and White Spot Syndrome Virus (WSSV) the causative agent of White Spot Disease are of major economic importance in the respective salmon and crustacean aquaculture sector $[18,19]$. Iridoviridae comprises a family of double stranded DNA virus that infect a wide variety of invertebrate and marine organisms, such as the genus Megalocytivirus, represented by red sea bream iridovirus (RSIV) [20, 21]. Ranavirus, another representative genus in the Iridovirdae family, is a global emergent pathogen capable of infecting fish, amphibians, and reptiles in both captive and wild animals causing hemorrhagic disease [22]. Betanodaviruses, which are non-enveloped single stranded RNA viruses, comprise an additional important family of viruses impacting the aquaculture industry $[23,24]$.

\section{Bacterial pathogens}

Among the most note-worthy bacterial aquatic pathogens is the warmwater bacterium Aeromonas hydrophila as well as its cold water relative Aeromonas salmonicida, which infect a variety of fish species in both the freshwater and marine environment. Among these susceptible fish species, tilapia, cyprinid $[25,26]$ and salmonid (salmon and trout) fish [26] are of particular economic importance. A bacterium that has mostly been studied in infecting salmonid is the enterobacterium Yersinia ruckeri, causative agent of then enteric redmouth disease, salmonid which has been associated with haemorrhages and petechial lesions in infected fish (Fig. 1; from personal archives) [27-29]. Moreover, the enterobacterium Edwardsiella ictaluri is considered one of the most important bacterial pathogen affecting the culture of catfish, in particular the channel catfish Ictalurus punctatus in the Southern United States [26] and, as it has been more recently reported, the striped catfish Pangasianodon hypophthalmus in Vietnam [30, 31]. In shrimp, bacterial infections are mostly linked to bacteria of the Vibrio family, in particularly to Vibrio parahaemolyticus which has recently been linked to an emergent disease termed acute hepatopancreatic necrosis disease [32].

\section{Parasites}

Parasitic diseases are often associated with more chronic diseases that can cause a sustained loss of productivity over the whole production cycle, and therefore the economical impact of these diseases can often be very significant. Among the most prominent parasitical diseases are the ones caused by myxozoans parasites such as Myxobolus cerebralis and Tetracapsuloides bryosalmonae, the causative agents of whirling disease and proliferative kidney diseases in salmonids, respectively $[33,34]$. Ciliates are common inhabitant of both the freshwater and marine environment. Among these species, Ichthyophthirius multifiliis (often shortened to "Ich") is associated with high levels of mortality (up to 100\%) in freshwater fish [35]. This external parasite has a life cycle comprised of three stages, including a trophonts stage during whith it feeds on the fish skin where it forms white circular lesions that leads to the disease colloquial name of "white spot disease" [35-37]. While I. multifiliis is limited to freshwater, another ciliated, Cryptocaryon irritans is found is saltwater that causes a very similar condition, sometime also referred to as "white spot disease" or "marine ich" [38].

In molluscs, two parasites are particularly noteworthy: Marteilia refringens and Bonamia ostreae which affects the European flat oyster Ostrea edulis. The impact of these parasites has led to the introduction of more resistant species of oyster termed Crassostrea gigas to replace Ostrea edulis as the most commonly cultivated oyster species. This manuscript will review some of the newest approaches used to study aquatic diseases, in terms of detection characterization and possible treatment strategies. 


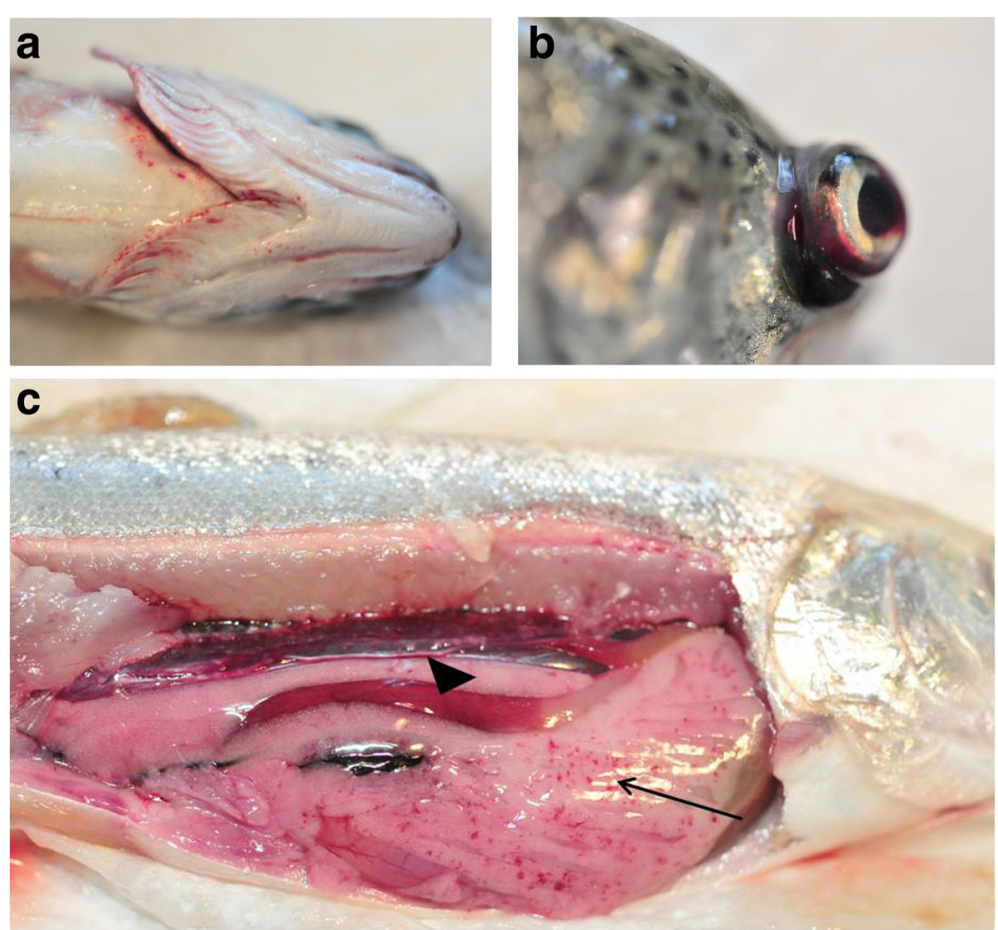

Fig. 1 Clinical signs in a rainbow trout (Oncorhynchus mykiss) infected with Yersinia ruckeri (from personal archives, previously unpublished). a Petechia and haemorrhages in the oral region; b Exophtalmia; $\mathbf{c}$ Large arrows- blood in the intestinal track and Small arrow- petechia in the visceral tissue

\section{Bio diagnostics/characterization \\ Rapid detection/nanotechnology}

Histological observation followed by polymerase chain reaction (PCR) [39], or cohabitation studies as performed by El-Matbouli \& Soliman [40] to demonstrate transmission of CyHV-3 virus from goldfish (Carassius auratus auratus) to naïve carp have been the classical method of detection and demonstration of transmission of pathogen(s) to new hosts. PCR-based methods coupled to electron microscopy have also been used in categorizing aquatic pathogens, such as in the classification of the parasitic ciliate infecting shrimp [41]. However, updated methods for rapid detection is required to tackle the rapid spread of communicable pathogens in aquatic farming, especially in densely populated environment used in aquaculture. For example, preliminary differentiation of CyHV-3 from channel catfish virus was performed by restriction analysis of purified DNA extracts and led to a PCR-based method detection [42, 43]. Subsequently, a 1 step process was developed using loop-mediated isothermal amplification (LAMP) without requiring a thermal cycler for detection of CyHV-3 [44-46]. Alternatively, nested PCR or the capture of viral particles by antibodies followed by LAMP can also be used for highly sensitive detection of CyHV-3 [47-49]. PCR based methods of detection can be coupled with DNA-array technology for rapid detection of secondary infections in diseased fish [50]. For rapid and visual based detection for CyHV-3, the product of LAMP-PCR is visualized by mixing with SYBR-Green I to confirm infection [51]. Attachment of single stranded DNA molecules to gold nanoparticles allows for rapid (15 min) and sensitive detection $\left(10^{-3}\right.$ TCID $\left._{50} \mathrm{ml}^{-1}\right)$ of SVCV RNA based on visualization (Fig. 2; reproduced from Saleh et al. [52] with permission from Springer Nature) of colloidal solution [53] and the procedure can be readily adapted for detection of aquatic viruses $[54,55]$. In addition to the various molecular based methods, immunohistochemistry in terms of histological assays [56] or enzyme-linked immunosorbent assay (ELISA) are also used to detect viral infections [57-63]. Detection of viral particles in affected species and carriers is important to combat the spread of outbreaks [64]. Recently, a method described as liquid chip which combines flow cytometry, nanometer fluorescent microspheres with traditional chemical luminescence technology has been described for rapid detection of several Rhabdoviridae members including SVCV, IHNV and VHSV [65].

\section{Characterization}

Traditionally, pathogens of aquatic organisms have been characterized by sequence analysis [66-69], and by microscopic examination of the pathogen and/or host by differing methods that include histological staining [70] and electron microscopy [71]. Recently, deep sequencing along with microarray hybridization has been used to 

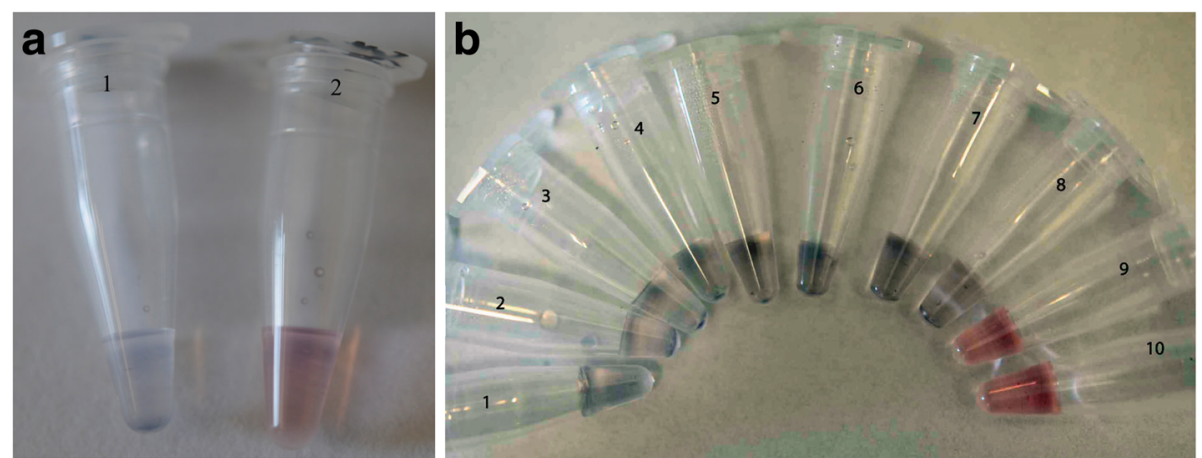

Fig. 2 Application of nanoparticles for the diagnostic of spring viraemia of carp virus. a Unmodified gold nanoparticles (AuNPs) for the colorimetric detection of spring viraemia of carp virus (SVCV)-RNA (from Saleh et al. [52], figure subject to copyright and reproduced with permission from Springer Nature). Tube 1: Positive SVCV-RNA sample (blue color). Tube 2: No template control (red color). Each tube contained $5 \mu \mathrm{l}$ of sample, $1.8 \mu \mathrm{M}$ of primer and $0.1 \mathrm{M} \mathrm{NaCl}$. b Serial dilution of SVC-RNA (Tubes 1 to 10 contain $10^{5}, 10^{4}, 10^{3}, 10^{2}, 10,10^{-1}, 10^{-2}, 10^{-3} 10^{-4}$ and $10^{-5} \mathrm{TCID}_{50} \mathrm{ml}^{-1}$ SVC-RNA respectively) showing the sensitivity limit of the assay. The SVC-AuNPs assay could detect SVCV-RNA as far as the $10^{-3} \mathrm{TCID}_{50} \mathrm{ml}^{-1}$ dilution (Tube 8; blue color)

identify pathogen microRNAs (miR) involved in gene regulation [72]. Similarly, real-time quantitative reverse transcription PCR (RT-qPCR) has been used to show differential expression of the host miR-10a-3p, a component of the master transcriptional regulator for spatial patterning genes termed homeobox (Hox) genes, during infections by VHSV rock bream iridovirus (RBIV) of olive flounder and rock bream [73]. Real-time quantitative PCR (qPCR) or deep RNA sequencing can be used in transcriptome analysis to characterize host-pathogen interactions [74]. Histological assays can be coupled with immunofluorescence techniques to further elaborate the ultrastructure make up of disease causing pathogens [75]. For example, indirect fluorescence immunohistochemistry was adapted to E. ictaluri using the monoclonal antibody Ed9 [76] as the primary antibody and a fluorescein isothiocyanate (FITC) labeled goat anti-mouse secondary antibodies [77]. This allowed identification of the bacteria with the tissue and contributed in demonstrating the role of abrasion sites as a route of infection for E. ictaluri in $I$. punctatus [78]. Reverse genetic experimentation in which the reading frame of various viral proteins are altered, such as the non-virion (NV) non-structural protein, $\mathrm{G}$ and $\mathrm{M}$ proteins, or recombinant viruses are produced has been used to investigate virulent factors in VHSV [79-83].

Several approaches have been applied to investigate the virulence mechanisms of bacterial pathogens. For example, in vivo induced antigen technology (IVIAT) relies on harvesting antibodies from host exposed to the pathogen of interest. The antibodies are then adsorbed against an in vitro culture of the pathogen, therefore removing the antibodies that react against antigens expressed in vitro. The only remaining antibodies, recognizing antigens specifically expressed in vivo, are then used to screen an expression library expressing random sequences from the pathogen genomes $[84,85]$. Regarding aquatic species, IVIAT has been used to investigate Edwardsiella tarda [86], Vibrio anguillarum [87] as well as A. salmonicida subsp. salmonicida $[88,89]$ and, more recently, Photobacterium damselae subsp. piscicida [90].

Gene expression profiling has been applied to I. multifiliis to identify genes that are differentially regulated during the different life stages of the parasite [91, 92]. This approach has led to the discovery that gene expression in I. multifillis is extremely stage specific [91] and has led to a better understanding of the expression of the virulence genes in this parasite. Moreover, it has been reported that senescence of the parasite was correlated to a lower expression for the genes of its Rickettsia endosymbiont [92]. Similarly, Mai et al. performed an immunoproteomic analysis of C. irritans [93] using 2D gels and anti-C. irritans antibodies isolated from both rabbit and grouper (Epinephelus coioides). This approach allowed to identify several proteins that were differentially regulated between life stages of the parasite, including several antigenic ones with potential in vaccine development. Among the isolation were proteins of the cytoskeletal apparatus ( $\beta$-tubulin and actin), as well as the enzyme enolase and the heat shock protein hsp70 [93]. Moreover, Yin et al. [94] conducted an analysis of the transcriptomes of trophont, either untreated or treated at either 12 or $25^{\circ} \mathrm{C}$. The authors described up-regulation of several genes required for the cell's survival at lower temperature and entry into dormancy [94].

\section{Proteomics}

Exogenous expression in bacteria of proteins found in aquatic pathogens followed by PAGE-Gel analysis and Western blotting with native proteins can be used to detect in vivo posttranslational modifications by differences in observed mass [95, 96]. Monoclonal antibodies against $\mathrm{CyHV}-3$ have been used to measure the expression 
kinetics of various proteins involved in protein assembly [97]. Analyses of whole proteomes have also been carried out; for example, in Y. ruckeri [98], where the proteomes of four different isolates were compared under iron-replete and iron-depleted conditions. This revealed the spread of the bacterium's response to iron depletion as 61 proteins were found to be differentially expressed (35 up and 26 down-regulated). Among these were several siderophores (iron acquisition molecules that play a crucial role in the microbial infection process when iron is often the bacteria's limiting factor) that were up-regulated and catalase that were down-regulated. Interestingly, the bacteria appeared to shift from iron-based superoxide dismutase (SodB, 28.6 fold downregulated) to manganese-based using a manganese based superoxide dismutase (SodA) that was 5.6-fold upregulated.

Differential transcriptional patterns obtained from qPCR based methods $[99,100]$ can be coupled to protein-based studies [101] to enhance our understanding of pathogen-host interactions. For protein purification, antibodies raised against the pathogen(s) of interest can be used to capture proteins involved in host-pathogen interactions which are subsequently identified by mass spectrometry [102]. Such studies have been used to differentiate between host pathogen interactions of susceptible carp versus carrier goldfish for CyHV-3 entry and replication [103, 104]. Additionally, proteomic based approach revealed that although all 156 open reading frames (ORFs) are CyHV-3 are transcribed during viral maturation [105], only 46 proteins are incorporated into mature virions [106, 107].Whereas, exogenous expression of viral proteins can demonstrate lethal properties for those proteins [108]. Therefore, proteomic should be used to enhance and elucidate transcriptional based data.

\section{Treatment RNA interference (RNAi)}

RNA mediated interference (RNAi) machinery is presumed to have developed as a defensive mechanism in eukaryotic organisms against viruses and transposable elements [109]. RNA-mediated interference (RNAi) by the use of short double-stranded RNA (dsRNA) was originally demonstrated in Caenorhabditis elegans by Fire et al. [110], and the mechanism and machinery for the function of small non-coding RNA in RNAi has since been worked out in great detail for a variety of organisms [111, 112]. During the post-transcriptional gene silencing (PTGS) of exogenous transcripts by RNAi, the RNA-induced silencing complex (RISC) converts long dsRNA transcripts into siRNA oligos (21-25 nt), which guide the complex by antisense complementation to degrade targeted genes [113]. RNAi technology has been important in understanding gene function in aquatic diseases [114] and can be used to study RNA-based viruses which are traditionally investigated by reverse genetics [115]. RNAi-based approaches are also suitable for the development of novel therapies against viral diseases of livestock and aquatic organisms and represent a promising method in developing novel therapeutics and antiviral medications [116]. A limited number of studies have reported about the treatment of viral diseases by RNAi, although RNAi based therapies for viral diseases have been in the pipeline to treat invertebrate, vertebrate and even human pathogens [117].

\section{Studies that used RNAi technology in aquatic medicine Viral}

In a recent study, feeding shrimp with bacteria coding for dsRNA that targeted endogenous shrimp non-essential Rab7 and STAT genes caused systemic induction of the RNAi pathway against the targeted genes [118]. The technique has been applied to provide protection from an important disease in shrimp farms, termed White spot syndrome virus (WSSV), by feeding shrimp with bacteria expressing dsRNA against several important viral genes [119]. Inhibition by RNAi of WSSV was first demonstrated in a non-Shrimp cell line, termed SISK, and by intramuscular injection of live shrimp [120,121], and the results were verified when shrimp were fed with dsRNA-transcribing bacteria [122]. Permanent epithelioma papulosum cyprini (EPC) and chinook salmon embryonic (CHSE-214) fish cell lines that express long dsRNA which target the $G$ protein of viral hemorrhagic septicemia virus (VHSV) inhibited in vitro replication of VHSV without stimulating the interferon pathway [123]. Treatment with formaldehyde-attenuated bacterial cells that produce dsRNA targeting the hemagglutinin gene of ISAV inhibited in vitro viral replication [124]. RNAi targeting the nucleoprotein ' $\mathrm{N}$ ' or phosphoprotein " $\mathrm{P}$ " has been shown to inhibit in vitro replication of SVCV [125]. Similarly, RNAi experiments targeting thymidine kinase 'TK' or DNA polymerase 'DP' of CyHV-3 inhibited in vitro replication [126]. CyHV-3 is most effectively inhibited by RNAi when multiple viral genes are targeted $[126,127]$.

\section{Bacterial/parasitic}

RNAi treatment has shown promising results in the treatment of parasitic infections in fish. Saleh et al. [128] demonstrated that in vitro RNAi knockdown of ATP/ ADP antiporter and methionine aminopeptidase II of the Heterosporis saurida, parasite of the lizardfish (Saurida undosquamis), reduced targeted gene transcription and spore counts in cell culture assays. Potential for RNAi-based medicine has been demonstrated in vivo by treating the oligochaete host Tubifex tubifex for the cnidarian myxozoan parasite (Myxobolus cerebralis) which causes whirling diseases in salmonid fish [129]. In subsequent 
trials, Sarker et al. [130] showed that T. tubifex soaked in solution containing dsRNA targeting the serine protease of the $M$. cerebralis inoculated the cnidarian myxozoan parasite from infecting the rainbow trout (Oncorhynchus mykiss) host.

\section{Is CRISPR/Cas based medicine on the horizon?}

Cre (causes recombination) and other tyrosine recombinases have traditionally been used for genomic editing. These tyrosine site-specific recombinases are typically used to reintegrate exogenous DNA flanked by palindromic into a host genome such as observed in the Cre/ Lox system in which Cre is used with the accompanying Lox palindromic DNA sequence [131]. A newer genome editing tool termed CRISPR/Cas (clustered regularly interspaced short palindromic repeats/CRISPR-associated), takes advantage of the prokaryotic and archaea immune system to reintegrate foreign DNA using a Cas protein and a guide RNA (gRNA) [132]. In addition to gene editing, the nuclease activity of the CRISPR/Cas pathway can be induced to degrade foreign RNA/DNA [133]. The CRISPR/Cas gene suppression technique was recently used by Zhao et al. [134] to confirm that RNAi knockdown of CyHV-3 TK and DP genes reduced viral replication and virus titer as reported previously by our group [126].

\section{Conclusion}

Prophylactic treatments, for example aiming at strengthening or preparing the immune response such as vaccination, are always preferable to therapeutic ones [135-138]. However, preventative therapies are not always possible or practical, therapies based on small nucleotide based medicine such as siRNA or CRISPR/Cas are on the horizon. RNAi-based technology has already been suggested to be useful in aquatic and fish medicine to combat various types of diseases caused by viral and parasitic agents $[116,139]$. Effectiveness of using RNAi or other nucleic based therapies rely on targeting pathogens transcripts that interfere with the hosts defensive capabilities used in viral entry or replication [140, 141]. RNAi and CRISPR/Cas mediated interference [133] along with the use small molecules to promote endogenous host response to viral infections [142, 143] are powerful emerging therapy strategies to deal with diseases in aquatic medicine. For those interesting cases where some aqua-species have become invasive, using a disease may be the methodology used to control the threat. For example, the release of CyHV-3 is seriously being considered to eradicate the invasive carp in Australia to restore populations of native fish species [144, 145] following the incidental example happening in the USA [146].

\section{Abbreviations}

CHSE-214: Chinook salmon embryonic; Cre: Causes recombination; CRISPR Cas: Clustered Regularly Interspaced Short Palindromic Repeats/CRISPR associated protein 9; CyHV-3: Cyprinid herpesvirus 3; EPC: Epithelioma papulosum cyprini; FITC: Fluorescein isothiocyanate; gRNA: Guide RNA; Hox: Homeobox; IHNV: Infectious hematopoietic necrosis virus; ISAV: Infectious salmon anaemia virus; IVIAT: In vivo induced antigen technology; KHVD: Koi herpesvirus disease; LAMP-PCR: Loop mediated isothermal amplification PCR; NV: Non-virion protein; PAGE-

Gel: Polyacrylamide gel electrophoresis gel; PCR: Polymerase chain reaction; qPCR: Real-time quantitative (RT) PCR; RBIV: Rock bream iridovirus; RNAi: RNA interference; RSIV: Red sea bream iridovirus (RSIV); siRNA: Small inhibitory Ribonucleic acid; SVCV: Spring viremia of carp virus; VHSV: Hemorrhagic septicemia virus; WSSV: White Spot Syndrome Virus

Ethic approval and consent to participate Not applicable

\section{Funding}

This research was supported by the Austrian Science Funds (Fonds zur Förderung der wissenschaftlichen Forschung), project P28837-B22. The funding body did not contribute to the study's design or analysis of the data.

Availability of data and materials

Data sharing not applicable to this article as no datasets were generated or analyzed during the current study.

\section{Authors' contributions}

MG, MS and SML conceived and drafted the manuscript. SMB and MEM supervised the writing and corrected the manuscript. All authors read and approved the final manuscript.

\section{Competing interests}

The authors declare that they have no competing interests.

\section{Publisher's Note}

Springer Nature remains neutral with regard to jurisdictional claims in published maps and institutional affiliations.

\section{Author details}

${ }^{1}$ Department of Biology, New York City College of Technology of the City University of New York, Brooklyn, New York, USA. ${ }^{2}$ Clinical Division of Fish Medicine, Department for Farm Animals and Veterinary Public Health, University of Veterinary Medicine, Veterinärplatz 1, 1210 Vienna, Austria. ${ }^{3}$ Institute of Infectology, Friedrich-Loffler-Institut (FLI), Federal Research Institute for Animal Health, Greifswald-Insel Riems, Germany.

Received: 10 January 2018 Accepted: 24 May 2018

Published online: 08 June 2018

\section{References}

1. FAO. The state of world fisheries and aquaculture. Rome: FAO; 2016.

2. FAO. State of the world fisheries and aquaculture- 2012. Rome: FAO Fisheries and Aquaculture Department; 2012.

3. Xie J, Lü L, Deng M, Weng S, Zhu J, Wu Y, et al. Inhibition of reporter gene and Iridovirus-tiger frog virus in fish cell by RNA interference. Virology. 2005; 338:43-52.

4. Zhang QY, Gui JF. Virus genomes and virus-host interactions in aquaculture animals. Sci China Life Sci. 2015;58:156-69.

5. Fujioka H, Yamasaki K, Furusawa K, Tamura K, Oguro K, Kurihara S, et al. Prevalence and characteristics of Cyprinid herpesvirus 3 (CyHV-3) infection in common carp (Cyprinus carpio L.) inhabiting three rivers in Kochi Prefecture, Japan. Vet Microbiol. 2015;175:362-8.

6. Rahmati-Holasoo H, Zargar A, Ahmadivand S, Shokrpoor S, Ezhari S, Ebrahimzadeh Mousavi HA. First detection of koi herpesvirus from koi, Cyprinus carpio L. experiencing mass mortalities in Iran: clinical, histopathological and molecular study. J Fish Dis. 2016;39:1153-63.

7. Mayrhofer R, Pucher J, Saleh M, Menanteau-Ledouble S, Bergmann S, Focken $U$, et al. First detection of cyprinid herpesvirus 3 in cultured common carp in Vietnam. Fish Pathol. 2016;51:28.

8. OIE. Manual of diagnostic tests for aquatic animals. 5th ed. Paris: OIE; 2009. 
9. Rakus K, Ouyang P, Boutier M, Ronsmans M, Reschner A, Vancsok C, et al. Cyprinid herpesvirus 3: an interesting virus for applied and fundamental research. Vet Res. 2013;44:85.

10. Gotesman M, Kattlun J, Bergmann SM, El-Matbouli M. CyHV-3: the third cyprinid herpesvirus. Dis Aquat Org. 2013;105:163-74.

11. Kattlun J, Gotesman M, Bergmann SM, El-Matbouli M. Die Erkrankung der Karpfen (Cyprinus carpio) mit dem Cypriniden Herpesvirus 3 (CyHV-3) - ein Update. Wiener Tierarztl Monatsschrift2. 2013;100:72-84.

12. Boutier M, Gao Y, Vancsok C, Suárez NM, Davison AJ, Vanderplasschen A. Identification of an essential virulence gene of cyprinid herpesvirus 3. Antivir Res. 2017;145:60-9.

13. Antychowicz J. Najnowsze badania nad etiologią, patogenezą, diagnostyką i zwalczaniem zakażenia karpi wirusem herpes karpia koi. Życie Weter. 2014:89:923-7.

14. Ashraf U, Lu Y, Lin L, Yuan J, Wang M, Liu X. Spring viraemia of carp virus: recent advances. J Gen Virol. 2016;97:1037-51.

15. Dixon P, Stone D. Spring viraemia of carp. Fish Viruses Bact. Pathobiol. Prot; 2017. p. 79-90.

16. Getchell RG, Cornwell ER, Bogdanowicz S, Andrés J, Batts WN, Kurath G, Breyta R, Choi JG, Farrell JM, Bowser PR. Complete sequences of 4 viral hemorrhagic septicemia virus IVb isolates and their virulence in northern pike fry. Dis Aquat Org. 2017;126:211-27.

17. Dixon P, Paley R, Alegria-Moran R, Oidtmann B. Epidemiological characteristics of infectious hematopoietic necrosis virus (IHNV): a review. Vet Res. 2016;47:63-89.

18. Cottet L, Rivas-Aravena A, Cortez-San Martin M, Sandino AM, Spencer E. Infectious salmon anemia virus - genetics and pathogenesis. Virus Res. 2011;155:10-9

19. Verbruggen B, Bickley L, van Aerle R, Bateman K, Stentiford G, Santos E, et al. Molecular mechanisms of white spot syndrome virus infection and perspectives on treatments. Viruses. 2016;8:23.

20. Chinchar VG, Waltzek TB, Subramaniam K. Ranaviruses and other members of the family Iridoviridae: their place in the virosphere. Virology. 2017;511: 259-71

21. Kurita J, Nakajima K. Megalocytiviruses. Viruses. 2012;4:521-38.

22. Duffus AL, Waltzek TB, Stöhr AC, Allender MC, Gotesman M, Whittington RJ, Hick P, Hines MK, Marschang RE. Distribution and host range of ranaviruses. In: Gray MJ, Chinchar VG, editors. Ranaviruses: lethal pathogens of ectothermic vertebrates 1. New York: Springer; 2015. p. 9-57.

23. Bonami JR, Widada JS. Viral diseases of the giant fresh water prawn Macrobrachium rosenbergii: a review. J Invertebr Pathol. 2011;106:131-42.

24. Shetty M, Maiti B, Santhosh KS, Venugopal MN, Karunasagar I. Betanodavirus of marine and freshwater fish: distribution, genomic organization, diagnosis and control measures. Indian J Virol. 2012;23:114-23.

25. Cipriano RC, Austin B. Furunculosis and other aeromonad diseases. In: Woo PT, Bruno DW, editors. Fish Dis. Disord. Vol. 3 viral, Bact. Fungal Infect. 2nd ed. Wallingford: CABl; 2011. p. 424-83. Available from: http://www.cabi.org/ cabebooks/ebook/20113056419.

26. Roberts RJ. The bacteriology of teleosts. In: Roberts RJ, editor. Fish Pathol. 4th ed. London: Wiley-Blackwell; 2012. p. 339-82.

27. Barnes AC. Enteric redmouth disease (ERM) (Yersinia ruckeri). Fish Dis. Disord. Vol. 3 viral, Bact. fungal Infect. Wallingford: CABl; 2011. p. 484-511.

28. Austin B, Austin DA. Bacterial fish pathogens. Cham: Springer International Publishing; 2016.

29. Kumar G, Menanteau-Ledouble S, Saleh M, El-Matbouli M. Yersinia ruckeri, the causative agent of enteric redmouth disease in fish. Vet Res. 2015;46:103.

30. Fergusson HW, Turnbull JF, Shinn A, Thompson KD, Dung TT, Crumlish M. Bacillary necrosis in farmed Pangasius hypophtalmus (Sauvage) from the Mekong Delta, Vietnam. J Fish Dis. 2001;24:509-13.

31. Crumlish $M$, Thanh PC, Koesling J, Tung VT, Gravningen K. Experimental challenge studies in Vietnamese catfish, Pangasianodon hypophthalmus (Sauvage), exposed to Edwardsiella ictaluri and Aeromonas hydrophila. J Fish Dis. 2010;33:717-22. Available from: http://doi.wiley.com/10.1111/j.13652761.2010.01173x

32. Lee C-T, Chen I-T, Yang Y-T, Ko T-P, Huang Y-T, Huang J-Y, et al. The opportunistic marine pathogen Vibrio parahaemolyticus becomes virulent by acquiring a plasmid that expresses a deadly toxin. Proc Natl Acad Sci. 2015; 112:10798-803.

33. Abd-Elfattah A, Kumar G, Soliman H, El-Matbouli M. Persistence of Tetracapsuloides bryosalmonae (Myxozoa) in chronically infected brown trout Salmo trutta. Dis Aquat Org. 2014;111:41-9.
34. Sarker S, Kallert DM, Hedrick RP, El-Matbouli M. Whirling disease revisited: pathogenesis, parasite biology and disease intervention. Dis Aquat Org. 2015;114:155-75.

35. Ruth F-F, Reed P. Ichthyophthirius multifiliis (White Spot) Infection in Fish. Circ. 920. 1997.

36. Matthews RA. Ichthyophthirius multifiliis Fouquet and Ichthyophthiriosis in Freshwater Teleosts. Adv Parasitol. 2005;59:159-241. Available from: http:// linkinghub.elsevier.com/retrieve/pii/S0065308X05590031

37. Saleh M, Abdel-Baki A-A, Dkhil MA, El-Matbouli M, Al-Quraishy S. Antiprotozoal effects of metal nanoparticles against Ichthyophthirius multifiliis. Parasitology. 2017;144:1802-10. Available from: https://www.cambridge.org/core/product/ identifier/S0031182017001184/type/journal_article

38. Wright A-DG, Colorni A. Taxonomic re-assignment of Cryptocaryon irritans, a marine fish parasite. Eur J Protistol. 2002;37:375-8. Available from: http:// linkinghub.elsevier.com/retrieve/pii/S0932473904700358

39. Langenmayer MC, Lewisch E, Gotesman M, Hoedt W, Schneider M, El-Matbouli $M$, et al. Cutaneous infection with Dermocystidium salmonis in cardinal tetra, Paracheirodon axelrodi (Schultz, 1956). J Fish Dis. 2015;38:503-6.

40. El-Matbouli M, Soliman H. Transmission of Cyprinid herpesvirus-3 (CyHV-3) from goldfish to naïve common carp by cohabitation. Res Vet Sci. 2011;90: 536-9.

41. Frischer ME, Lee RF, Price AR, Walters TL, Bassette MA, Verdiyev R, Torris MC, Bulski K, Geer PJ, Powell SA, Walker AN. Causes, diagnostics, and distribution of an ongoing penaeid shrimp black gill epidemic in the US South Atlantic Bight. J Shellfish Res. 2017;36:487-500.

42. Gilad O, Yun S, Andree K, Adkison M, Zlotkin A, Bercovier H, et al. Initial characteristics of koi herpesvirus and development of a polymerase chain reaction assay to detect the virus in koi, Cyprinus carpio koi. Dis Aquat Org. 2002;48:101-8.

43. Aoki T, Hirono I, Kurokawa K, Fukuda H, Nahary R, Eldar A, et al. Genome sequences of three koi herpesvirus isolates representing the expanding distribution of an emerging disease threatening koi and common carp worldwide. J Virol. 2007;81:5058-65.

44. Gunimaladevi I, Kono T, Venugopal MN, Sakai M. Detection of koi herpesvirus in common carp, Cyprinus carpio L., by loop-mediated isothermal amplification. J Fish Dis. 2004;27:583-9.

45. Yoshino M, Watari H, Kojima T, Ikedo M, Kurita J. Rapid, sensitive and simple detection method for koi herpesvirus using loop-mediated isothermal amplification. Microbiol Immunol. 2009;53:375-83.

46. Yoshino M, Watari H, Kojima T, Ikedo M. Sensitive and rapid detection of koi herpesvirus by LAMP method. Fish Pathol. 2006;41:19-27.

47. El-Matbouli M, Saleh M, Soliman H. Detection of cyprinid herpesvirus type 3 in goldfish cohabiting with CyHV-3-infected koi carp (Cyprinus carpio koi). Vet Rec. 2007;161:792-3.

48. Soliman H, El-Matbouli M. Immunocapture and direct binding loop mediated isothermal amplification simplify molecular diagnosis of Cyprinid herpesvirus-3. J Virol Methods. 2009;162:91-5.

49. Bergmann SM, Riechardt M, Fichtner D, Lee P, Kempter J. Investigation on the diagnostic sensitivity of molecular tools used for detection of koi herpesvirus. J Virol Methods. 2010;163:229.

50. Lievens B, Frans I, Heusdens C, Justé A, Jonstrup SP, Lieffrig F, et al. Rapid detection and identification of viral and bacterial fish pathogens using a DNA array-based multiplex assay. J Fish Dis. 2011;34:861-75.

51. Soliman H, El-Matbouli M. An inexpensive and rapid diagnostic method of Koi Herpesvirus (KHV) infection by loop-mediated isothermal amplification. Virol J. 2005;2:83.

52. Saleh M, Soliman H, El-Matbouli M. Gold nanoparticles as a potential tool for diagnosis of fish diseases. In: Inácio J, Cunha M V., editors. Methods Mol Biol. 2015;1247:245.

53. Saleh M, Soliman H, Schachner O, El-Matbouli M. Direct detection of unamplified spring viraemia of carp virus RNA using unmodified gold nanoparticles. Dis Aquat Org. 2012;100:3-10.

54. Saleh M, El-Matbouli M. Rapid detection of Cyprinid herpesvirus-3 (CyHV-3) using a gold nanoparticle-based hybridization assay. J Virol Methods. 2015; 217:50-4.

55. Shaalan M, Saleh M, El-Mahdy M, El-Matbouli M. Recent progress in applications of nanoparticles in fish medicine: a review. Nanomedicine. 2016:12:701-10.

56. Aoki T, Takano T, Unajak S, Takagi M, Kim YR, Bin PS, et al. Generation of monoclonal antibodies specific for ORF68 of koi herpesvirus. Comp Immunol Microbiol Infect Dis. 2011;34:209-16. 
57. Adkison MA, Gilad O, Hedrick RP. An Enzyme Linked Immunosorbent Assay (ELISA) for detection of antibodies to the Koi Herpesvirus (KHV) in the Serum of Koi Cyprinus carpio. Fish Pathol. 2005;40:53-62.

58. Bergmann SM, Engler C, Wang Q, Zeng W, Li Y, Wang Y, et al. Investigation on antigen ELISA for detection of the envelope glycoprotein coded by ORF 149 of investigation on antigen ELISA for detection of the envelope glycoprotein coded by ORF 149 of different koi herpesvirus isolates obtained from cell cultures. J Vet Sci Med. 2017;5:1-7.

59. Cabon J, Louboutin L, Castric J, Bergmann S, Bovo G, Matras M, et al. Validation of a serum neutralization test for detection of antibodies specific to cyprinid herpesvirus 3 in infected common and koi carp (Cyprinus carpio). J Fish Dis. 2017:40:687-701

60. Dishon A, Perelberg A, Bishara-Shieban J, llouze M, Davidovich M, Werker S, et al. Detection of carp interstitial nephritis and gill necrosis virus in fish droppings. Appl Environ Microbiol. 2005;71:7285-91.

61. St-Hilaire S, Beevers N, Joiner C, Hedrick RP, Way K. Antibody response of two populations of common carp, Cyprinus carpio L., exposed to koi herpesvirus. J Fish Dis. 2009;32:311-20.

62. Torrent F, Villena A, Lee PA, Fuchs W, Bergmann SM, Coll JM. The aminoterminal domain of ORF149 of koi herpesvirus is preferentially targeted by IgM from carp populations surviving infection. Arch Virol. 2016;161:2653-65.

63. Wang $H, X u L, L u L$. Detection of cyprinid herpesvirus 2 in peripheral blood cells of silver crucian carp, Carassius auratus gibelio (Bloch), suggests its potential in viral diagnosis. J Fish Dis. 2016;39:155-62.

64. Gaede L, Steinbrück J, Bergmann SM, Jäger K, Gräfe H, Schoon HA, et al. Koi herpesvirus infection in experimentally infected common carp Cyprinus carpio (Linnaeus, 1758) and three potential carrier fish species Carassius carassius (Linnaeus, 1758); Rutilus rutilus (Linnaeus, 1758); and Tinca tinca. J Appl Ichthyol. 2017;33:776-84.

65. Tong G, Wei X, Yin W, Liao X, Yang K, Fang Z, Sun T, Yue Z, Li X. Development of a liquid chip technique to simultaneously detect spring viremia of carp virus, infectious hematopoietic necrosis virus, and viral hemorrhagic septicemia of salmonids. J AOAC Int. 2017;100:159-64.

66. Waltzek TB, Kelley GO, Stone DM, Way K, Hanson L, Fukuda H, et al. Koi herpesvirus represents a third cyprinid herpesvirus (CyHV-3) in the family Herpesviridae. J Gen Virol. 2005;86:1659-67.

67. Li W, Lee X, Weng S, He J, Dong C. Whole-genome sequence of a novel Chinese cyprinid herpesvirus 3 isolate reveals the existence of a distinct European genotype in East Asia. Vet Microbiol. 2015;175:185-94.

68. Lee $X, Y i$ Y, Weng S, Zeng J, Zhang H, He J, et al. Transcriptomic analysis of koi (Cyprinus carpio) spleen tissue upon cyprinid herpesvirus 3 (CyHV3) infection using next generation sequencing. Fish Shellfish Immunol. 2016; 49:213-24.

69. Zeng X-T, Chen Z-Y, Deng Y-S, Gui J-F, Zhang Q-Y. Complete genome sequence and architecture of crucian carp Carassius auratus herpesvirus (CaHV). Arch Virol. 2016;161:3577-81.

70. Monaghan SJ, Thompson KD, Adams A, Bergmann SM. Sensitivity of seven PCRs for early detection of koi herpesvirus in experimentally infected carp, Cyprinus carpio L., by lethal and non-lethal sampling methods. J Fish Dis. 2015;38:303-19.

71. Subramaniam K, Gotesman M, Smith CE, Steckler NK, Kelley KL, Groff JM, et al. Megalocytivirus infection in cultured Nile tilapia Oreochromis niloticus. Dis Aquat Org. 2016;119:253-8.

72. Donohoe $\mathrm{OH}$, Henshilwood K, Way K, Hakimjavadi R, Stone DM, Walls D. Identification and Characterization of Cyprinid Herpesvirus-3 (CyHV-3) encoded MicroRNAs. Pfeffer S, editor. PLoS One. 2015;10:e0125434.

73. Jo A, Im J, Lee HE, Jang D, Nam GH, Mishra A, Kim WJ, Kim W, Cha HJ, Kim HS. Evolutionary conservation and expression of miR-10a-3p in olive flounder and rock bream. Gene. 2017;628:16-23.

74. Yuan J, Yang Y, Nie H, Li L, Gu W, Lin L, et al. Transcriptome analysis of epithelioma papulosum cyprini cells after SVCV infection. BMC Genomics. 2014;15:935.

75. Rosenkranz D, Klupp BG, Teifke JP, Granzow H, Fichtner D, Mettenleiter TC, et al. Identification of envelope protein pORF81 of koi herpesvirus. J Gen Virol. 2008;89:896-900.

76. Ainsworth J, Capley G, Waterstreet P, Munson D. Use of monoclonal antibodies in the indirect fluorescent antibody technique (IFA) for the diagnosis of Edwardsiella ictaluri. J Fish Dis. 1986:9:439-44.

77. Menanteau-Ledouble S, Lawrence M. Use of Fluorescent Immuno-Chemistry for the detection of Edwardsiella ictaluri in channel catfish(I. punctatus) samples. J Vis Exp. 2011;(51):e2687. https://doi.org/10.3791/2687.
78. Menanteau-Ledouble S, Karsi A, Lawrence ML. Importance of skin abrasion as a primary site of adhesion for Edwardsiella ictaluri and impact on invasion and systematic infection in channel catfish Ictalurus punctatus. Vet Microbiol. 2011;148:425-30.

79. Baillon L, Mérour E, Cabon J, Louboutin L, Quenault H, Touzain F, Morin T, Blanchard $Y$, Biacchesi S, Brémont M. A single amino acid change in the non-structural NV protein impacts the virulence phenotype of Viral hemorrhagic septicemia virus in trout. J Gen Virol. 2017:98:1181-4.

80. Chinchilla B, Gomez-Casado E. Identification of the functional regions of the viral haemorrhagic septicaemia virus (VHSV) NV protein: variants that improve function. Fish Shellfish Immunol. 2017;70:343-50.

81. Sun $T$, Yin WL, Fang BH, Wang Q, Liang CZ, Yue ZQ. Prediction of G gene epitopes of viral hemorrhagic septicemia virus and eukaryotic expression of major antigen determinant sequence. Cell Mol Biol. 2017;63:84-8.

82. Ke Q, Weaver W, Pore A, Gorgoglione B, Wildschutte JH, Xiao P, Shepherd BS, Spear A, Malathi K, Stepien CA, Vakharia VN. Role of viral hemorrhagic septicemia virus matrix (M) protein in suppressing host transcription. J Virol. 2017;91:e00279-17.

83. Kwak JS, Kim MS, Kim KH. Generation of a recombinant viral hemorrhagic septicemia virus (vhsv) expressing olive flounder (paralichthys olivaceus) interferon- $y$ and its effects on type I interferon response and virulence. Fish Shellfish Immunol. 2017;68:530-5.

84. Handfield M, Brady LJ, Progulske-Fox A, Hillman JD. IVIAT: a novel method to identify microbial genes expressed specifically during human infections. Trends Microbiol. 2000:8:336-9.

85. Rollins SM, Peppercorn A, Hang L, Hillman JD, Calderwood SB, Handfield M, et al. In vivo induced antigen technology (IVIAT). Cell Microbiol. 2005;7:1-9.

86. Jiao XD, Dang W, Hu YH, Sun L. Identification and immunoprotective analysis of an in vivo-induced Edwardsiella tarda antigen. Fish Shellfish Immunol. 2009;27:633-8.

87. Zou YX, Mo ZL, Hao B, Ye XH, Guo DS, Zhang PJ. Screening of genes expressed in vivo after infection by Vibrio anguillarum M3. Lett Appl Microbiol. 2010;51:564-9.

88. Menanteau-ledouble S, Soliman H, Kumar G, El-Matbouli M. Use of in vivo induced antigen technology to identify genes from Aeromonas salmonicida subsp. salmonicida that are specifically expressed during infection of the rainbow trout Oncorhynchus mykiss. BMC Vet Res. 2014;10:1-11.

89. Menanteau-Ledouble S, El-Matbouli M. Antigens of Aeromonas salmonicida subsp. salmonicida specifically induced in vivo in Oncorhynchus mykiss. J Fish Dis. 2016;39:1015-9.

90. Núñez-Díaz JA, Fumanal M, Viguera E, Moriñigo MA, Balebona MC. Use of in vivo induced technology to identify antigens expressed by Photobacterium damselae subsp. piscicida during infection of Senegalese sole (Solea senegalensis). Fish Shellfish Immunol. 2017;64:446-56.

91. Cassidy-Hanley DM, Cordonnier-Pratt M-M, Pratt LH, Devine C, Mozammal Hossain M, Dickerson HW, et al. Transcriptional profiling of stage specific gene expression in the parasitic ciliate Ichthyophthirius multifiliis. Mol Biochem Parasitol. 2011;178:29-39. Available from: https://doi.org/10.1016/j.molbiopara.2011.04.004

92. Abernathy J, Xu D-H, Peatman E, Kucuktas H, Klesius P, Liu Z. Gene expression profiling of a fish parasite Ichthyophthirius multifiliis: insights into development and senescence-associated avirulence. Comp Biochem Physio Part D Genomics Proteomics. 2011;6:382-92. Available from: https://doi.org/ 10.1016/j.cbd.2011.08.003

93. Mai Y-Z, Li Y-W, Li R-J, Li W, Huang X-Z, Mo Z-Q, et al. Proteomic analysis of differentially expressed proteins in the marine fish parasitic ciliate Cryptocaryon irritans. Vet Parasitol. 2015;211:1-11. Available from: https://doi. org/10.1016/j.vetpar.2015.05.004

94. Yin F, Sun P, Wang J, Gao Q. Transcriptome analysis of dormant tomonts of the marine fish ectoparasitic ciliate Cryptocaryon irritans under low temperature. Parasit Vectors. 2016;9:280. Available from: https://doi.org/10. 1186/s13071-016-1550-1

95. Fuchs W, Granzow H, Dauber M, Fichtner D, Mettenleiter TC. Identification of structural proteins of koi herpesvirus. Arch Virol. 2014;159:3257-68.

96. Reed AN. The conserved biology of herpesvirus latency: a study in cyprinid herpesvirus 3. Oregon State University; 2014.

97. Monaghan SJ, Thompson KD, Bron JE, Bergmann SM, Jung TS, Aoki T, et al. Expression of immunogenic structural proteins of cyprinid herpesvirus 3 in vitro assessed using immunofluorescence. Vet Res. 2016;47:8.

98. Kumar G, Hummel K, Ahrens M, Menanteau-Ledouble S, Welch TJ, Eisenacher $\mathrm{M}$, et al. Shotgun proteomic analysis of Yersinia ruckeri strains under normal and iron-limited conditions. Vet Res. 2016;47:100. 
99. Kumar G, Abd-elfattah A. Identification of differentially expressed genes of brown trout (Salmo trutta) and rainbow trout (Oncorhynchus mykiss) in response to Tetracapsuloides bryosalmonae (Myxozoa). Parasitol Res. 2015; 1792:929-39.

100. Kumar G, Sarker S, Menanteau-Ledouble S, El-Matbouli M. Tetracapsuloides bryosalmonae infection affects the expression of genes involved in cellular signal transduction and iron metabolism in the kidney of the brown trout Salmo trutta. Parasitol Res. 2015;114:2301-8.

101. Kumar G, Gotesman M, El-Matbouli M. Interaction of Tetracapsuloides bryosalmonae, the causative agent of proliferative kidney disease, with host proteins in the kidney of Salmo trutta. Parasitol Res. 2015;144:1721-7.

102. Gotesman M, Menanteau-Ledouble S, El-Matbouli M. Proteomic analysis of cytoskeleton proteins in fish. In: Gavin RH, editor. Cytoskelet. Methods Protoc. SE - 21. Springer New York; 2016. p. 357-72.

103. Gotesman M, Soliman H, El-Matbouli M. Antibody screening identifies 78 putative host proteins involved in Cyprinid herpesvirus 3 infection or propagation in common carp, Cyprinus carpio L. J Fish Dis. 2013;36:721-33.

104. Gotesman M, Abd-Elfattah A, Kattlun J, Soliman H, El-Matbouli M. Investigating the interactions of Cyprinid herpesvirus-3 with host proteins in goldfish Carassius auratus. J Fish Dis. 2014;37:835-41.

105. Ilouze M, Dishon A, Kotler M. Coordinated and sequential transcription of the cyprinid herpesvirus-3 annotated genes. Virus Res. 2012;169:98-106.

106. Michel B, Leroy B, Stalin Raj V, Lieffrig F, Mast J, Wattiez R, et al. The genome of cyprinid herpesvirus 3 encodes 40 proteins incorporated in mature virions. J Gen Virol. 2010;91:452-62

107. Yi Y, Zhang H, Lee $X$, Weng S, He J, Dong C. Extracellular virion proteins of two Chinese CyHV-3/KHV isolates, and identification of two novel envelope proteins. Virus Res. 2014;191:108-16.

108. Yi Y, Qi H, Yuan J, Wang R, Weng S, He J, et al. Functional characterization of viral tumor necrosis factor receptors encoded by cyprinid herpesvirus 3 (CyHV3) genome. Fish Shellfish Immunol. 2015;45:757-70.

109. Obbard DJ, Gordon KHJ, Buck AH, Jiggins FM. The evolution of RNAi as a defence against viruses and transposable elements. Philos Trans R Soc Lond Ser B Biol Sci. 2009;364:99-115.

110. Fire A, Xu S, Montgomery MK, Kostas SA, Driver SE, Mello CC. Potent and specific genetic interference by double-stranded RNA in Caenorhabditis elegans. Nature. 1998;391:806-11.

111. Mochizuki K. DNA rearrangements directed by non-coding RNAs in ciliates. Wiley Interdiscip Rev RNA. 2010;1:376-87.

112. Sifuentes-Romero I, Milton SL, García-Gasca A. Post-transcriptional gene silencing by RNA interference in non-mammalian vertebrate systems: where do we stand? Mutat Res. 2011;728:158-71.

113. Kim K, Lee YS, Harris D, Nakahara K, Carthew RW. The RNAi pathway initiated by Dicer-2 in Drosophila. Cold Spring Harb Symp Quant Biol. 2006; 71:39-44.

114. Reshi ML, Wu J-L, Wang H-V, Hong J-R. RNA interference technology used for the study of aquatic virus infections. Fish Shellfish Immunol. 2014;40:14-23.

115. Biacchesi S. The reverse genetics applied to fish RNA viruses. Vet Res. 2011; 42:12.

116. Lima PC, Harris JO, Cook M. Exploring RNAi as a therapeutic strategy for controlling disease in aquaculture. Fish Shellfish Immunol. 2013;34:729-43.

117. Hammond SM. MicroRNA therapeutics: a new niche for antisense nucleic acids. Trends Mol Med. 2006;12:99-101.

118. Attasart $P$, Namramoon O, Kongphom U, Chimwai C, Panyim S. Ingestion of bacteria expressing dsRNA triggers specific RNA silencing in shrimp. Virus Res. 2013;171:252-6.

119. Sarathi M, Simon MC, Venkatesan C, Thomas J, Ravi M, Madan N, et al. Efficacy of bacterially expressed dsRNA specific to different structural genes of white spot syndrome virus (WSSV) in protection of shrimp from WSSV infection. J Fish Dis. 2010;33:603-7.

120. Sarathi M, Simon MC, Ahmed VPI, Kumar SR, Hameed ASS. Silencing VP28 gene of white spot syndrome virus of shrimp by bacterially expressed dsRNA. Mar Biotechnol. 2008;10:198-206.

121. Xu J, Han F, Zhang X. Silencing shrimp white spot syndrome virus (WSSV) genes by siRNA. Antivir Res. 2007;73:126-31.

122. Sarathi M, Simon MC, Venkatesan C, Hameed ASS. Oral administration of bacterially expressed VP28dsRNA to protect Penaeus monodon from white spot syndrome virus. Mar Biotechnol. 2008;10:242-9.

123. Kim MS, Jee BY, Cho MY, Kim JW, Do JH, Kim KH. Fugu double U6 promoter-driven long double-stranded RNA inhibits proliferation of viral hemorrhagic septicemia virus (VHSV) in fish cell lines. Arch Virol. 2012;157: 1029-38.

124. García K, Ramírez-Araya S, Díaz Ã, Reyes-Cerpa S, Espejo RT, Higuera G, et al. Inactivated E. coli transformed with plasmids that produce dsRNA against infectious salmon anemia virus hemagglutinin show antiviral activity when added to infected ASK cells. Front Microbiol. 2015;6:1-11.

125. Gotesman M, Soliman H, Besch R, El-Matbouli M. Inhibition of spring viraemia of carp virus replication in an Epithelioma papulosum cyprini cell line by RNAi. J Fish Dis. 2015;38:197-207.

126. Gotesman M, Soliman H, Besch R, El-Matbouli M. In vitro inhibition of cyprinid herpesvirus-3 replication by RNAi. J Virol Methods. 2014;206:63-6.

127. Adamek M, Rauch G, Brogden G, Steinhagen D. Small interfering RNA treatment can inhibit cyprinid herpesvirus 3 associated cell death in vitro. Pol J Vet Sci. 2014;17:733-5.

128. Saleh M, Kumar G, Abdel-Baki A-A, Dkhil MA, El-Matbouli M, Al-Quraishy S. In vitro gene silencing of the fish microsporidian Heterosporis saurida by RNA interference. Nucleic Acid Ther. 2016:26:250-6.

129. Sarker S, El-Matbouli M. Can RNAi target salmonid whirling disease in vivo ? Nucleic Acid Ther. 2015;25:285-6.

130. Sarker S, Menanteau-Ledouble S, Kotob MH, El-Matbouli MA. RNAi-based therapeutic proof of concept targets salmonid whirling disease in vivo. Vazquez-Duhalt R, editor. PLoS One. 2017;12:e0178687.

131. Meinke G, Bohm A, Hauber J, Pisabarro MT, Buchholz F. Cre recombinase and other tyrosine recombinases. Chem Rev. 2016:116:12785-820.

132. Hryhorowicz M, Lipiński D, Zeyland J, Słomski R. CRISPR/Cas9 immune system as a tool for genome engineering. Arch Immunol Ther Exp. 2017;65: 233-40.

133. Chin WX, Ang SK, Chu JJH. Recent advances in therapeutic recruitment of mammalian RNAi and bacterial CRISPR-Cas DNA interference pathways as emerging antiviral strategies. Drug Discov Today. 2017;22:17-30.

134. Zhao Y, Wang T, Yu Z, Wang H, Liu B, Wu C, et al. Inhibiting cyprinid herpesvirus-3 replication with CRISPR/Cas9. Biotechnol Lett. 2016;38:573-8.

135. Kattlun J, Menanteau-Ledouble S, El-Matbouli M. Non-structural protein pORF 12 of cyprinid herpesvirus 3 is recognized by the immune system of the common carp Cyprinus carpio. Dis Aquat Org. 2014;111:269-73.

136. Kattlun J, Menanteau-Ledouble S, Gotesman M, Abd-Elfattah A, Way K, Soliman $\mathrm{H}$, et al. Immunogenic potential of a membrane protein encoded by the viral gene located at ORF 81 of Cyprinid Herpesvirus-3. Wien Tierarztl Monatsschr. 2016;103:3-12.

137. Monaghan SJ. Approaches to DIVA vaccination for fish using infectious salmon anaemia and koi herpesvirus disease as models. University of Stirling; 2013.

138. Monaghan SJ, Thompson KD, Smith PD, Adams A. Potential of DIVA vaccines for fish. Fish vaccines. Basel: Springer Basel; 2016. p. 143-73.

139. Samir M, Pessler F. Small non-coding RNAs associated with viral infectious diseases of veterinary importance: potential clinical applications. Front Vet Sci. 2016;3:22.

140. Feng H, Zhang Y-B, Zhang Q-M, Li Z, Zhang Q-Y, Gui J-F. Zebrafish IRF1 regulates IFN antiviral response through binding to IFN $\varphi 1$ and IFN $\varphi 3$ promoters downstream of MyD88 signaling. J Immunol. 2015;194:1225-38.

141. Lu L-F, Li S, Lu X-B, LaPatra SE, Zhang N, Zhang X-J, et al. Spring viremia of carp virus $\mathrm{N}$ protein suppresses fish IFN $\varphi 1$ production by targeting the mitochondrial antiviral signaling protein. J Immunol. 2016;196:3744-53.

142. Liu L, Hu Y, Shen Y-F, Wang G-X, Zhu B. Evaluation on antiviral activity of coumarin derivatives against spring viraemia of carp virus in epithelioma papulosum cyprini cells. Antivir Res. 2017;144:173-85.

143. Liu L, Tu X, Shen YF, Chen WC, Zhu B, Wang GX. The replication of spring viraemia of carp virus can be regulated by reactive oxygen species and NFKB pathway. Fish Shellfish Immunol. 2017;67:211-7.

144. McColl KA, Sunarto A, Williams LM, Crane MSTJ. The koi herpesvirus: dreaded pathogen or white knight? Aquac Heal Int. 2007;9:4-6.

145. McColl KA, Sunarto A, Holmes EC. Cyprinid herpesvirus 3 and its evolutionary future as a biological control agent for carp in Australia. Virol J. 2016;13:206.

146. Gibson-Reinemer DK, Chick JH, VanMiddlesworth TD, VanMiddlesworth M Casper AF. Widespread and enduring demographic collapse of invasive common carp (Cyprinus carpio) in the upper Mississippi River system. Biol Invasions. 2017:19:1905-16. 